\title{
Molecular characterisation of 34 patients with biotinidase deficiency ascertained by newborn screening and family investigation
}

\author{
Adolf Mühl*,1, Dorothea Möslinger ${ }^{1}$, Chike B Item ${ }^{1}$ and Silvia Stöckler-Ipsiroglu ${ }^{1}$ \\ ${ }^{1}$ Department of Pediatrics, University Hospital Vienna, Währinger Gürtel 18-20, A-1090 Vienna, Austria
}

This study characterises the spectrum of biotinidase mutations in 21 patients (17 families) with profound biotinidase deficiency (BD) and 13 unrelated patients with partial BD using a denaturing gradient gel electrophoretic mutation screening and selective sequencing approach. In 29 from 30 unrelated families we found biallelic mutations including four common mutations, D444H (frequency $23.3 \%), \mathrm{G} 98: \mathrm{d} 7 \mathrm{i3}(20.0 \%)$, $\mathrm{Q} 456 \mathrm{H}(20.0 \%), \mathrm{T} 532 \mathrm{M}(15.0 \%)$ and nine rare mutations $(\mathrm{V} 62 \mathrm{M}, \mathrm{R} 157 \mathrm{H}, \mathrm{A} 171 \mathrm{~T}+\mathrm{D} 444 \mathrm{H}, \mathrm{C} 423 \mathrm{~W}, \mathrm{D} 543 \mathrm{H}$, L279W, N172S, V109G, 12236G-A) with frequencies less than $5.0 \%$. Only three profound BD patients with G98:d7i3/G98:d7i3 and Q456H/Q456H genotypes and residual biotinidase activities of $0.0 \%$, and $0.9 \%$ of normal activity developed clinical symptoms before biotin supplementation at 8 weeks of age. All other patients remained asymptomatic within the first months of life or even longer without treatment. Two patients homozygous for the frameshift mutation $\mathrm{G} 98: \mathrm{d} 7 \mathrm{i} 3$ had no measurable residual enzyme activity. Twelve patients with partial BD had the D444H mutation in at least one allele. We conclude that, based on mutation analysis and biochemical examinations of the enzyme, it is currently not clearly predictable whether an untreated patient will develop symptoms or not, although it seems that patients with activities lower than $1 \%$ are at a high risk for developing symptoms of the disease early in life. European Journal of Human Genetics (2001) 9, 237-243.

Keywords: biotinidase deficiency; mutations; denaturing gradient gel electrophoresis

\section{Introduction}

Biotinidase deficiency (BD) (McKusick 25326) is an autosomal recessive inherited disorder affecting the endogenous recycling of biotin (vitamin $\mathrm{H}$ ). Consecutive biotin depletion results in low activities of biotin-dependent carboxylases and urinary excretion of organic acids characteristic of multiple carboxylase deficiency. Clinical features include seizures, muscular hypotonia, various neurologic deficits, skin abnormalities, and metabolic ketoacidosis which finally may result in coma and early death. Treatment with pharmacological doses of biotin results in rapid clinical improvement,

*Correspondence: Adolf Mühl, PhD, Department of Pediatrics, University Hospital Vienna, Währinger Gürtel 18-20, A-1090 Vienna, Austria.

Tel: +43 40400 3156; Fax: +43 1 4033484; E-mail: adolf.muehl@univie.ac.at Received 4 May 2000; revised 3 November 2000; accepted 14 December 2000 but residual neurologic damage has been reported in cases with delayed onset of treatment. ${ }^{1}$

With the introduction of newborn screening for $\mathrm{BD},{ }^{2}$ not only those children with profound biotinidase deficiency (residual activity $<10 \%$ ), but also a group of children with $10-30 \%$ residual activity (partial biotinidase deficiency) have been identified.

The human biotinidase gene is of average size and complexity consisting of 4 exons with a total length of 1629 bp. $^{3,4}$ So far, more than 40 mutations causing biotinidase deficiency have been described. ${ }^{5-9}$

We have identified 21 patients with profound and 13 patients with partial bitotinidase deficiency during a 12 year nationwide newborn screening in nearly 1 million newborns and by subsequent family investigations.

The aim of this study was to establish a denaturing gradient gel electrophoretic technique for mutation screening, con- 
sequent characterisation of mutations on the biotinidase gene in these patients and to establish a correlation genotype-phenotype.

\section{Materials and methods \\ Reagents}

All chemicals were purchased from Perkin Elmer unless otherwise noted. Oligonucleotides were synthesised by MWG-Biotech, Ebersberg, Germany. Ampli-Taq DNA polymerase was purchased from ViennaLab, Vienna, Austria.

\section{DNA isolation}

DNA was purified according to the manufacturers instructions from a 3-mm blood soaked filter paper disk, using the Nucleospin C+T kit, Machery Nagel, Germany. DNA from whole blood was extracted by standard procedures.

\section{Primer design and PCR amplification}

Primers for amplification of 16 overlapping fragments of the biotinidase gene, ranging from $200-400 \mathrm{bp}$ in length, were selected using the OLIGO primer analysis program. ${ }^{10}$ The melting characteristics and the optimal positioning of a 40 base pair GC-clamp ${ }^{11}$ at the end of the fragments were determined empirically using the computer program MELT94. ${ }^{12}$ Using the primers given in Table 1 polymerase chain reaction (PCR) amplification was performed in $50 \mu \mathrm{l}$ volumes containing $4 \mu \mathrm{l}$ of DNA isolated from blood spots or $100 \mathrm{ng}$ of DNA isolated from whole blood. For all PCR amplifications we used a buffer containing $10 \mathrm{~mm}$ Tris- $\mathrm{HCl}, \mathrm{pH} 9.0,50 \mathrm{~mm} \mathrm{KCl}, 1.5 \mathrm{~mm}$ $\mathrm{MgCl}_{2}, 0.1 \%$ Triton $\mathrm{X}-100,0.01 \%$ gelatine, and $1 \mathrm{U}$ TaqPolymerase. For all fragments $100 \mu$ m of each dNTP and $800 \mathrm{~nm}$ of each primer were used. For fragments Exon $3 b$ and Exon $4 b$ the $\mathrm{Mg}$ concentration was increased to $5 \mathrm{~mm}$.

After an initial denaturation for $7 \mathrm{~min}$ at $95^{\circ} \mathrm{C}$, samples were processed through 40 thermal cycles of $60 \mathrm{~s}$ denaturation at $94^{\circ} \mathrm{C}, 60 \mathrm{~s}$ annealing at $55^{\circ} \mathrm{C}$, followed by $60 \mathrm{~s}$ elongation at $72^{\circ} \mathrm{C}$ in a Perkin Elmer-DNA Thermo Cycler.

After amplification, the samples were boiled for $5 \mathrm{~min}$ and slowly cooled to $37^{\circ} \mathrm{C}$ to permit the formation of heteroduplexes.

Denaturing gradient gel electrophoresis (DGGE) Twenty microlitres of PCR product was loaded on a gel containing a linear gradient of urea and formamide in $1 \times$ TAE buffer ( $7 \mathrm{~m}$ urea and $40 \%$ formamide $=100 \%$ denaturants), as

Table 1 Amplification primers and DGGE conditions

\begin{tabular}{|c|c|c|c|c|c|}
\hline Fragments & Primer sequence & $\begin{array}{l}\text { Length of } \\
\text { product }(b p)\end{array}$ & $\begin{array}{l}\text { Denaturant } \\
\text { range }(\%)\end{array}$ & $\begin{array}{l}\mathrm{Tm} \\
\left({ }^{\circ} \mathrm{C}\right)\end{array}$ & Domains/length \\
\hline Exon 1 & 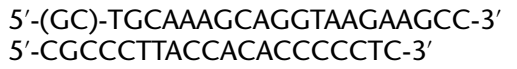 & 220 & $30-70$ & 80 & $1 / 160$ \\
\hline Exon $2 a$ & $\begin{array}{l}\text { 5'-(GC)-AAATTCTTGGCAGGATTCTT-3' } \\
\text { 5'-CACGСTCTCСTCCCCGGTGT-3' }\end{array}$ & 200 & $20-60$ & 74 & $1 / 160$ \\
\hline Exon $2 b$ & $\begin{array}{l}\text { 5'-CGTGGTTGCCCTGGGAGCCC-3' } \\
\text { 5'-(GC)-TTACCCAACCACTGATCAA-3' }\end{array}$ & 320 & $20-60$ & 75 & $1 / 270$ \\
\hline Exon $3 a$ & $\begin{array}{l}\text { 5'-(GC)-TGCCATCTGATAACAGACTA-3' } \\
\text { 5'-GGGGAGACGGCATGAAGTC-3' }\end{array}$ & 180 & $10-50$ & 67 & $1 / 130$ \\
\hline Exon $3 b$ & $\begin{array}{l}\text { 5'-ATGGATTCAACTTTACAAGA-3' } \\
\text { 5'-(GC)-TCACСТCTGTGTACCCTCAG-3' }\end{array}$ & 200 & $20-60$ & 75 & $1 / 110$ \\
\hline Exon $4 a$ & $\begin{array}{l}\text { 5'-GGGTGGTCTCAATCTCCTGA-3' } \\
\text { 5'-(GC)-CGACATTTGTGTTGAACTGG-3' }\end{array}$ & 280 & $10-50$ & 73 & $1 / 220$ \\
\hline Exon $4 b$ & $\begin{array}{l}\text { 5'-CATCAGGGGAGATATGTTCT-3' } \\
\text { 5'-(GC)-ATATATCAAAGCATGTGAAG-3' }\end{array}$ & 280 & $10-50$ & 72 & $1 / 220$ \\
\hline Exon $4 c$ & $\begin{array}{l}\text { 5'-(GC)-CAGCATTCGATGTTCCTCTT-3' } \\
\text { 5'-AACTGGGTGGTGGACATTAG-3' }\end{array}$ & 300 & $10-50$ & 72 & $1 / 260$ \\
\hline Exon 4d & $\begin{array}{l}\text { 5'-TGGCAGCAATTGAGATTCAG-3' } \\
\text { 5-(GC)-GGACTTCCTGAGCATCCTTC-3' }\end{array}$ & 340 & $10-50$ & 72 & $1 / 260$ \\
\hline Exon $4 \mathrm{e}$ & $\begin{array}{l}\text { 5'-(GC)-CCATCCCATAGTAAGTTTाT-3' } \\
5^{\prime} \text {-TGGGCСTCTCGTAAAGTAAA-3' }\end{array}$ & 269 & $10-50$ & 72 & $1 / 210$ \\
\hline Exon $4 f$ & $\begin{array}{l}\text { 5'-(GC)-ATGCTCCTCCCACATTTCAC-3' } \\
\text { 5'-GTGAAACTCAAАTATCCCCG-3' }\end{array}$ & 330 & $10-50$ & 73 & $1 / 270$ \\
\hline Exon $4 \mathrm{~g}$ & $\begin{array}{l}\text { 5'-TACTACATCCAGTGTGTGC-3' } \\
\text { 5'-(GC)-GGTCATTCTCCCAGCCAAGC-3' }\end{array}$ & 236 & $10-50$ & 73 & $1 / 140$ \\
\hline Exon $4 \mathrm{~h}$ & $\begin{array}{l}\text { 5'-(GC)-ACCTGTGGGGCAACTTCAGT-3' } \\
\text { 5'-ATGGTCCCAGGGCTTGTAGC-3' }\end{array}$ & 302 & $20-60$ & 74 & $1 / 240$ \\
\hline Prom 1 & $\begin{array}{l}\text { 5'-(GC)-GTCCCCGCCAGCTTCCGTAG-3' } \\
\text { 5'-СТСTTCСTTCССGTTGTTTA-3' }\end{array}$ & 325 & $20-60$ & 77 & $1 / 250$ \\
\hline Prom 2 & $\begin{array}{l}\text { 5'-(GC)-GCAGCACGCCACCTCTGGTA-3' } \\
\text { 5'-CGCCATTCTCCCTTTACAGC-3' }\end{array}$ & 357 & $20-60$ & 76 & $1 / 260$ \\
\hline 3'-UTR & $\begin{array}{l}\text { 5'-TTGGCTGGGAGAATGACCAC-3' } \\
\text { 5'-(GC)-CCСССTAATGTCTCGATGAT-3' }\end{array}$ & 351 & $20-60$ & 75 & $1 / 270$ \\
\hline
\end{tabular}

$(\mathrm{GC})=5^{\prime}$-CGCCCGCCGCGCCCCGCGCCGTCCCGCCGCCCCCGCCCG-3'. 
described, ${ }^{13}$ and a linear gradient of polyacrylamide from 6 to $12 \% .{ }^{14}$ Electrophoresis was performed at $160 \mathrm{~V}$ for 5 to $6 \mathrm{~h}$ or at $100 \mathrm{~V}$ for $16 \mathrm{~h}$ overnight in $1 \times$ TAE buffer at $60^{\circ} \mathrm{C}$, using a DCode-Universal Mutation Detection System (BioRad, Hercules, CA, USA). Gels were stained with ethidium bromide.

\section{DNA-sequencing}

In case of abnormal DGGE banding pattern sequencing of the affected DNA was carried out. Sequencing was performed on a LI-COR 4200 system by a commercial sequencing service (MWG-Biotech, Ebersberg, Germany).

\section{Biotinidase activity}

Biotinidase activities were measured with a HPLC assay as previously published. ${ }^{15}$ Reference values were $6.00 \pm 1.11 \mathrm{nmol} / \mathrm{min} / \mathrm{ml}$. By this assay, biotinyl hydrolase activity is determined. Due to its high sensitivity, it allows exact determination of extremely low residual activities even below $1 \%$ of normal.

\section{Results}

Mutation detection by DGGE and identification of mutations by automated sequencing

DGGE procedures were established for the 4 exon regions and the proposed promoter region ${ }^{4}$ of the biotinidase gene (Table
1). Putative mutations were detected by the presence of an abnormal banding pattern of that particular region of the biotinidase gene when compared with that of normal controls on the same gel.

In every case with abnormal DGGE banding pattern, sequencing identified a nucleotide sequence difference when compared with the sequence of the normal biotinidase gene and the sequence from control individuals with normal biotinidase activity. Any nucleotide change that altered the protein translation of the gene was considered a putative mutation in this family.

\section{Sequence changes associated with profound biotinidase} deficiency

We studied 21 individuals from 17 families with profound BD. The mutations identified in our patients with profound BD are summarised in Table 2.

We found three common mutations $(\mathrm{Q} 456 \mathrm{H}, \mathrm{T} 532 \mathrm{M}$, G98:d7i3) accounting for about 55\% of all BD alleles. The remaining profound $\mathrm{BD}$ alleles are shared by two previously described mutations $\mathrm{R} 157 \mathrm{H}^{5}$ and the double mutation allele $\mathrm{A} 171 \mathrm{~T}+\mathrm{D} 444 \mathrm{H},{ }^{16}$ by four novel candidate $\mathrm{BD}$ mutations (V62M, C423W, D543H, 12236G-A), and by one unidentified mutation.

The first common mutation, G98:d7i3 was found in 20.0\% of all BD alleles. Our two homozygous patients (P1, P2) were

Table 2 Molecular characterisation of children with profound biotinidase deficiency

\begin{tabular}{|c|c|c|c|c|c|c|c|c|c|}
\hline Patient & $\begin{array}{l}\text { BD } \\
\text { activity } \\
\% \text { of } \\
\text { mean } \\
\text { control } \\
\text { value }\end{array}$ & $\begin{array}{l}\text { Mutations } \\
\text { allele } 1\end{array}$ & $\begin{array}{l}\text { Result of } \\
\text { mutation on } \\
\text { allele } 1\end{array}$ & $\begin{array}{l}\text { Mutations } \\
\text { allele } 2\end{array}$ & $\begin{array}{l}\text { Result of } \\
\text { mutation on } \\
\text { allele } 2\end{array}$ & $\begin{array}{l}\text { Country of } \\
\text { origin }\end{array}$ & $\begin{array}{l}\text { Symptoms } \\
\text { before } \\
\text { biotin } \\
\text { therapy }\end{array}$ & $\begin{array}{l}\text { Biotin } \\
\text { therapy } \\
\text { start at } \\
\text { age of }\end{array}$ & $\begin{array}{l}\text { Psychomotor outcome/ } \\
\text { latest test for } \\
\text { intelligence quotient IQ } \\
\text { (at age of) }\end{array}$ \\
\hline P1 & 0 & G98:d7i3 & Frameshift & G98:d7i3 & Frameshift & Austria & yes & $8 w$ & $\begin{array}{l}\text { neurology normal/Denver } \\
\text { normal (18 mo) }\end{array}$ \\
\hline P2 & 0 & G98:d7i3 & Frameshift & G98:d7i3 & Frameshift & Turkey & no (yes) & $5 w$ & neurology normal/no test \\
\hline P3 & 0.2 & G98:d7i3 & Frameshift & $470 \mathrm{G}>\mathrm{A}$ & $\mathrm{R} 157 \mathrm{H}$ & Turkey & no & $6 \mathrm{yrs}$ & neurology normal/IQ 66 (6y) \\
\hline P4 & 0.9 & G98:d7i3 & Frameshift & $1368 \mathrm{~A}>\mathrm{C}$ & Q456H & Austria & no & $7 \mathrm{w}$ & neurology normal/no test \\
\hline P5 & 0.9 & $1368 A>C$ & Q456H & $1368 A>C$ & Q456H & Austria & yes & $8 w$ & neurology normal/IQ 108.5 (6y) \\
\hline P8 & 1.5 & $1595 \mathrm{C}>\mathrm{T}$ & T532M & $1595 \mathrm{C}>\mathrm{T}$ & T532M & Turkey & no & $6 w$ & neurology normal/IQ 85.5 \\
\hline P34 & 1.5 & G98:d7i3 & Frameshift & $184 \mathrm{G}>\mathrm{A}$ & V62M & Austria & no & & \\
\hline P9 & 1.8 & $1368 \mathrm{~A}>\mathrm{C}$ & $\mathrm{Q} 456 \mathrm{H}$ & $511 G>A+1330 G>C$ & $\mathrm{~A} 171 \mathrm{~T}+\mathrm{D} 444 \mathrm{H}$ & Austria & no & $7 \mathrm{w}$ & neurology normal/IQ 109 (6y) \\
\hline P10 & 1.8 & $1368 A>C$ & Q456H & $1595 \mathrm{C}>\mathrm{T}$ & T532M & Yugoslavia & no & $7 \mathrm{w}$ & neurology normal/IQ 85 (10y) \\
\hline P12 & 2.8 & $1595 \mathrm{C}>\mathrm{T}$ & T532M & $1595 \mathrm{C}>\mathrm{T}$ & T532M & Turkey & no & 3.5 yrs & neurology normal/IQ 114 (6y) \\
\hline P7 & 2.9 & $1368 A>C$ & Q456H & $1368 A>C$ & Q456H & Yugoslavia & no & $3.5 \mathrm{yrs}$ & neurology normal/IQ 65 (6y) \\
\hline $\mathrm{P} 13^{\mathrm{x}}$ & 3.4 & $470 G>A$ & $\mathrm{R} 157 \mathrm{H}$ & $12236 \mathrm{G}>\mathrm{A}$ & Post transcr. & Turkey & no & 14 yrs & neurology normal/IQ 77 (24y) \\
\hline $\mathrm{P} 14^{\mathrm{x}}$ & 3.5 & $470 \mathrm{G}>\mathrm{A}$ & R157H & $12236 \mathrm{G}>\mathrm{A}$ & Post transcr. & Turkey & no & $8 w$ & neurology normal/IQ 87 (10y) \\
\hline $\mathrm{P} 15^{\mathrm{x}}$ & 4.6 & $470 \mathrm{G}>\mathrm{A}$ & R157H & $12236 \mathrm{G}>\mathrm{A}$ & Post transcr. & Turkey & no & 4 yrs & neurology normal/IQ 87 (14y) \\
\hline P16 & 4.4 & $1595 \mathrm{C}>\mathrm{T}$ & T532M & $1595 \mathrm{C}>\mathrm{T}$ & T532M & Yugoslavia & no & $7 \mathrm{w}$ & $\begin{array}{l}\text { neurology normal/Denver } \\
\text { normal (18 mo) }\end{array}$ \\
\hline P17 & 5.2 & $184 \mathrm{G}>\mathrm{A}$ & V62M & $1268 \mathrm{G}>\mathrm{C}$ & C423W & Austria & no & $1 \mathrm{yr}$ & $\begin{array}{l}\text { delayed speech development/ } \\
\text { IQ } 102.5(6 y)\end{array}$ \\
\hline $\mathrm{P} 18^{\mathrm{y}}$ & 5.9 & $1368 A>C$ & Q456H & ? & ? & Austria & no & 6 mon & neurology normal/IQ 100 (10y) \\
\hline P35 & 6.8 & $1595 \mathrm{C}>\mathrm{T}$ & T532M & $1627 G>C$ & D543H & Turkey & no & & \\
\hline $\mathrm{P} 19^{\mathrm{y}}$ & 8.4 & $1368 \mathrm{~A}>\mathrm{C}$ & Q456H & $?$ & $?$ & Austria & no & $4 \mathrm{w}$ & neurology normal/IQ 104 (6y) \\
\hline $\mathrm{P} 20^{\mathrm{y}}$ & 8.7 & $1368 A>C$ & $\mathrm{Q} 456 \mathrm{H}$ & ? & ? & Austria & no & $1.5 \mathrm{yrs}$ & neurology normal/IQ 101 (10y) \\
\hline P21 & 9.0 & G98:d7i3 & Frameshift & $1330 G>C$ & D444H & Poland & no & $5 w$ & lost for follow up \\
\hline
\end{tabular}

$x, y$ siblings from the same family. 
the only ones with no measurable residual enzyme activity. As the G98:d7i3 mutation is a null mutation, ${ }^{5}$ the residual biotinidase activities in the three compound heterozygous patients must be due to the proteins transcribed from their second alleles. Four patients (P3, P4, P34, P21) were compound heterozygotes with the mutations $\mathrm{R} 157 \mathrm{H}$, $\mathrm{Q} 456 \mathrm{H}, \mathrm{V} 62 \mathrm{M}$, and $\mathrm{D} 444 \mathrm{H}$ on the second allele and residual enzyme activities of $0.2,0.9,1.5$ and $9.0 \%$, respectively.

The second common mutation, $\mathrm{Q} 456 \mathrm{H}$ was found in $20.0 \%$ of all BD alleles. Two patients (P5, P7) were homozygous with 0.9 and $2.9 \%$ residual biotinidase activities. Five patients were compound heterozygotes with $\mathrm{Q} 456 \mathrm{H}$ on the first allele. P9 with the double mutation $\mathrm{A} 171 \mathrm{~T}+\mathrm{D} 444 \mathrm{H}$ on the second allele and $1.8 \%$ residual biotinidase activity. This patient is the only patient with the double mutation allele in our study. In contrast, in a US study this allele was identified as a common cause of profound BD in 14 out of 31 enzyme deficient children ascertained by newborn screening. ${ }^{16}$ Three Austrian siblings (P18, P19, P20), with 5.9, 8.4 and $8.7 \%$ residual activity respectively, had no additional mutation on the second allele. Complete sequencing of the coding regions, the intron/exon borders, the promoter region, and the $3^{\prime}$ untranslated sequence of the gene did not reveal an additional sequence change. We conclude that there must be a mutation in one of the introns possibly creating an alternative splice site or a large deletion encompassing other exons than the one containing Q456H.

The third common mutation, T532M was found in $15.0 \%$ of all BD alleles. Three unrelated patients (P8, P12, P16) were homozygous, with $1.5,2.8$ and $4.4 \%$ residual biotinidase activities respectively. Two patients (P8, P10) were compound heterozygous with $\mathrm{Q} 456 \mathrm{H}$ and $\mathrm{D} 543 \mathrm{H}$ on the second allele and 1.8 and $6.8 \%$ residual biotinidase activities respectively. Interestingly, we found an $\mathrm{A}$ to $\mathrm{C}$ sequence change at position 401 in the promoter region of the biotinidase gene sequence (EMBL accession no. AF018630) in both alleles of the patients homozygous for the T532M mutation, and in one allele in the individuals heterozygous for the T532M mutation. This sequence change does not alter any of the proposed functional elements of the promoter, ${ }^{4}$ but seems to be coinherited with the T532M mutation in cis.

$\mathrm{R} 157 \mathrm{H}$ was found in $3.3 \%$ of all $\mathrm{BD}$ alleles. The four patients (P3, P13, P14, P15) carrying the mutation came from two families of Turkish ethnic origin. Patient P3 was a compound heterozygote with the common mutation G98:d7i3 and $0.2 \%$ residual enzyme activity. The three siblings P13, P14 and P15 were compound heterozygous with a $\mathrm{G}$ to A sequence change at position 12236 in the $3^{\prime}$ UTR region of the biotinidase gene (EMBL accession no. AF018630) on the second allele. Residual enzyme activities were $3.4,3.5$ and $4.6 \%$ respectively. Two of these siblings (P13, P14) were clinically asymptomatic when diagnosed at age 4 and 14 years by family investigation. Biotinidase activity of their mother and of one unaffected sister, who were both carriers for the $12236 \mathrm{G}-\mathrm{A}$ sequence change, was about $60 \%$ of normal.

Three further novel candidate BD mutations (V62M, C423W, D543H) were found in $9.4 \%$ of BD alleles in two Austrian and one Turkish patients. Evidence for these novel mutations causing profound BD is based on the absence of other mutations on the patients defective allele, and the failure to detect these base changes in 100 control alleles. V62M was found in two unrelated Austrian patients (P17, P34). Patients were compound heterozygous with G98:d7i3, and the novel candidate mutation C423W on the second allele with residual enzyme activities of $1.5 \%$ and $5.2 \%$ respectively.

D543H was found together with $\mathrm{T} 532 \mathrm{M}$ in a Turkish patient (P35) whose residual enzyme activity was $6.8 \%$.

\section{Sequence changes associated with partial biotinidase deficiency}

We studied 13 nonconsanguinous children with partial BD. The mutations identified in our patients are summarised in Table 3.

It was previously reported that the major cause of partial $\mathrm{BD}$ is the mutation $\mathrm{D} 444 \mathrm{H}$ in one allele of the biotinidase gene in combination with a mutation that results in profound BD in the other allele. ${ }^{8}$ D $444 \mathrm{H}$ is the most common BD allele found in our population with a frequency of $24.2 \%$.

Nine of the 13 children had this mutation in at least one allele together with a mutation that causes profound $\mathrm{BD}$ (G98:d7i3, Q456H, T532M, V62M) in the other allele. Residual biotinidase activity of these patients is between 18.8 and $36.3 \%$ of mean normal activity.

Two patients (P23, P25) had the D444H mutation together with the novel mutations V109G and L279W, and residual enzyme activities of 18.0 and $18.9 \%$ of mean normal activity. One patient (P37) was homozygous for the D444H mutation and with a residual enzyme activity of $28.9 \%$.

One patient (P22) with residual activity of $13.8 \%$ did not carry the $\mathrm{D} 444 \mathrm{H}$ mutation. He was a compound heterozygote with the mutations $\mathrm{Q} 456 \mathrm{H}$ on the first allele and the novel mutation N172S on the second allele.

\section{Discussion}

This study characterises the spectrum of biotinidase mutations in 30 families with BD using a DGGE mutation screening and selective sequencing approach.

\section{Denaturing gradient gel electrophoresis}

Among the mutation screening methods, DGGE is not yet the most widely used. Depending on the melting temperature of the DNA fragment different conditions have to be found and optimised. DGGE fits most of the criteria for an optimal technique, being accurate, relatively fast, inexpensive, easy to perform, while avoiding the use of any radioactive material. 
Table 3 Molecular characterisation of children with partial biotinidase deficiency

\begin{tabular}{|c|c|c|c|c|c|c|}
\hline Patient & $\begin{array}{l}\text { BD activity } \\
\% \text { of mean } \\
\text { control value }\end{array}$ & $\begin{array}{l}\text { Mutations on } \\
\text { allele } 1\end{array}$ & $\begin{array}{l}\text { Results of } \\
\text { mutation } \\
\text { on allele } 1\end{array}$ & $\begin{array}{l}\text { Mutations on } \\
\text { allele } 2\end{array}$ & $\begin{array}{l}\text { Results of } \\
\text { mutations } \\
\text { on allele } 2\end{array}$ & $\begin{array}{l}\text { Country of } \\
\text { origin }\end{array}$ \\
\hline P22 & 13.8 & $515 A>G$ & N172S & $1368 A>C$ & Q456H & Austria \\
\hline P23 & 18.0 & $1330 G>C$ & D444H & $326 \mathrm{~T}>\mathrm{G}$ & V109G & Austria \\
\hline P24 & 18.8 & $1330 G>C$ & D444H & $184 G>A$ & V62M & Austria \\
\hline P25 & 18.9 & $1330 G>C$ & D444H & $836 \mathrm{~T}>\mathrm{G}$ & L279W & Austria \\
\hline P26 & 19.3 & $1330 G>C$ & $\mathrm{D} 444 \mathrm{H}$ & G98:d7i3 & Frameshift & Austria \\
\hline P27 & 20.2 & $1330 G>C$ & D444H & G98:d7i3 & Frameshift & Austria \\
\hline P28 & 21.1 & $1330 G>C$ & D444H & G98:d7i3 & Frameshift & Austria \\
\hline P29 & 22.3 & $1330 G>C$ & D444H & $1368 \mathrm{~A}>C$ & $\mathrm{Q} 456 \mathrm{H}$ & Austria \\
\hline P31 & 24.4 & $1330 G>C$ & D444H & G98:d7i3 & Frameshift & Austria \\
\hline P32 & 25.0 & $1330 G>C$ & D444H & $1595 C>T$ & T532M & Austria \\
\hline P36 & 28.0 & $1330 G>C$ & D444H & $1368 \mathrm{~A}>C$ & Q456H & Austria \\
\hline P33 & 28.9 & $1330 G>C$ & D444H & $1368 \mathrm{~A}>\mathrm{C}$ & Q456H & Austria \\
\hline P37 & 28.9 & $1330 G>C$ & D444H & $1330 G>C$ & $\mathrm{D} 444 \mathrm{H}$ & Austria \\
\hline
\end{tabular}

To make the DGGE technique successful for the application reported here, we have introduced an additional polyacrylamide gradient. ${ }^{14}$ The polyacrylamide gradient significantly suppresses band broadening even in lengthy electrophoretic runs, thus allowing uniform run times and conditions for many different DNA fragments, while maintaining the zone sharpening effect. The enhanced resolution of homo- and heteroduplexes obtained with this modification improves the diagnostic power of the technique, allowing better assignment of a single banding pattern to a specific mutation. This double gradient DGGE technique could detect all sequence changes in the DNA fragments examined.

DGGE of the 4 exon regions of the biotinidase gene detected 59 (98.3\%) of the 60 expected mutant alleles in the 30 families with profound and partial BD (Tables 2 and 3). DGGE also detected the previously described polymorphism C1413T in one out of 50 control samples. ${ }^{5}$ DGGE could detect only one mutant allele in a family with siblings P18, P19 and P20 (Table 2). Direct sequence analysis of the exons, exon/intron boundaries, the proposed promoter region, and the $3^{\prime}$ untranslated region, respectively, did not reveal a second mutation in this family.

\section{Mutations}

In our patients with profound BD G98:d7i3, Q456H, D444H and $\mathrm{T} 532 \mathrm{M}$ account for $73.3 \%$ of the $\mathrm{BD}$ alleles. In a previous report R538C, together with G98:d7i3 and Q456H were found to be most common in patients with profound BD. ${ }^{5}$ Interestingly, we could not find R538C in any of our patients, whereas we found $\mathrm{T} 532 \mathrm{M}$ as a fourth common mutation which is characterised by a substitution of threonine by methionine. This mutation was previously found to be common in Turkish children ascertained by newborn screening. ${ }^{9}$ It is also the most common mutation in our six Turkish families. Q456H was most common in patients with profound BD ascertained by newborn screening in the US. ${ }^{8}$ It was found in $28 \%$ of the nonconsanguinous alleles, which is almost equal to the frequency of $24.8 \%$ in our patients. Biochemical studies on a Q456H homozygous patient with $6.9 \%$ residual enzyme activity suggest that this mutation has a significant effect on the functional properties of the enzyme protein. As this patient had profoundly deficient biotinyl-hydrolase activity and complete absence of biotinyltransferase activity, it was speculated that the absence of biotinyl-transferase activity may be an indicator as to whether children with profound BD will develop symptoms if they would not be treated with biotin early in life. ${ }^{8}$ This speculation is not supported in our observations in patient $\mathrm{P7}$, who is Q456H homozygous, but was still asymptomatic at age 3.5 years despite no treatment. On the other hand, an other Q456H homozygous patient (P5) showed moderate symptoms (dermatitis, 3-hydroxyisovaleric aciduria) at age 8 weeks when therapy was started.

We found two patients (P1, P2) homozygous for the frameshift mutation G98:d7i3, which is a null mutation. ${ }^{5}$ Taking the results of our enzyme assay which has been proven extremely sensitive in patients with residual biotinidase activity $<1 \%{ }^{14}$ it is clearly shown that only these two patients homozygous for that null mutation have $0 \%$ biotinidase activity, whereas in all other patients traces of biotinidase activity could be found.

The spectrum of mutations in our patients with partial BD is in good agreement with previous findings. ${ }^{17}$ Partial BD is usually due to the mutation $\mathrm{D} 444 \mathrm{H}$ in one allele and a mutation causing profound BD in the other allele. Twelve $(92 \%)$ of our partial BD patients are carrying the $\mathrm{D} 444 \mathrm{H}$ mutation in at least one allele. Biotinidase activity of our patients carrying the $\mathrm{D} 444 \mathrm{H}$ mutation is between 19 and $36 \%$ of normal. Patient P22 has the new mutation N172S together with the $\mathrm{Q} 456 \mathrm{H}$ mutation. As the $\mathrm{Q} 456 \mathrm{H}$ mutation is known to cause profound $\mathrm{BD}$, the N172S mutation can be considered as a further mutation causing partial BD if it occurs in combination with a profound BD causing mutation. 


\section{New mutations}

In this study, seven new mutations were found and one possible mutation remained unidentified. Five of the new mutations (V62M, C423W, L279W, N172S, V109G) were found in Austrian and two (D543H, 12236G-A) in Turkish patients. All new mutations were private mutations found in a single patient except mutation V62M which was found in three unrelated Austrian patients. Evidence for these novel mutations causing profound BD is based on the absence of other mutations on the patients defective allele, and the failure to detect these base changes in 100 control alleles. Some of the rare mutations found only in single patients could still represent rare polymorphisms. Complete sequencing of the introns of that patients was not done.

The mutation C423W causes replacement of cystein by tryptophan and may alter disulfid bond formation and prevent proper conformational folding of the enzyme protein. $\mathrm{D} 543 \mathrm{H}$ is a substitution of an acidic aspartic acid by a basic histidine and occurs only two amino acid residues from the carboxy-terminus of the protein. It has been shown that mutations near the carboxy-terminus of the biotinidase protein abolish enzyme activity. ${ }^{6,7}$ We speculate that the $12236 \mathrm{G}>\mathrm{A}$ sequence change in the $3^{\prime}$ untranslated region of the biotinidase gene has some severe effects on posttranscriptional processes. All other new mutations cause aminoacid replacements of the same chemical type, ie nonpolar by nonpolar aminoacid (Val62Met, Val109Gly, Leu279Trp) and polar neutral by polar neutral aminoacid (Asn172Ser). Thus the effects of these mutations on the mature protein are not quite clear. One possibility is that they may be involved in the active centre of the enzyme.

The mutation N172S can be considered as a further mutation causing partial $\mathrm{BD}$, if it occurs together with a profound BD causing allele. Due to the significantly lower biotinidase activity (13\%) of the partial BD patient P22 with genotype Q456H/N172 compared to the three patients with genotype Q456H/D444H (22.3\%, 28.0\%, 28.9\%), one can assume that the N172S mutation has a much more severe effect on the enzyme function than the $\mathrm{D} 444 \mathrm{H}$ mutation.

\section{Correlation genotype/phenotype}

We had two patients with $0 \%$ residual enzyme activity (P1,P2) homozygous for the frameshift null mutation G98:d7i3. Patient P1 developed symptoms (severe encephalopathy, organic aciduria) before biotin substitution was initiated at 8 weeks after birth, whereas P2 was only moderately symptomatic at 5 weeks of age when treatment was started. The only other patient with early symptoms (dermatitis, 3-hydroxy isovaleric aciduria) was P5 who had $0.9 \%$ residual enzyme activity and was homozygous for Q456H. Although patient P7 had the same genotype the phenotype was quite different. He had $2.9 \%$ residual activity and was still asymptomatic at age 3.5 years when therapy was initiated.
We had five further patients (P3, P12, P17, P18, P20) with residual enzyme activities between 0.2 and $8.7 \%$ who were not treated with biotin in the first year after birth. All of them were asymptomatic at the age $(6,3.5,1,0.5,1.5$ years) therapy was started. The mutation spectrum of these patients is quite heterogenous and no correlation of a specific mutation to the lack of symptoms, the residual enzyme activity or the IQ can be seen (Table 2).

\section{Conclusion}

We conclude that, based on mutation analysis at the current state of knowledge, it is not clearly predictable whether an untreated patient will develop symptoms or not. However, we believe it is essential to differentiate biochemically between patients with $>1 \%$ and those with $<1 \%$ residual biotinidase activity, as the latter group particularly appears to have the highest risk to develop symptoms later in life.

\section{Acknowledgements}

This study has been supported by the Scientific Foundation of the Austrian National Bank (ÖNB Project 7633), and by the National Austrian Newborn Screening Program. We are grateful to Regula Baumgartner and Terttu Suormala (University Children's Hospital Basel) for measuring biotinidase activity.

\section{References}

1 Wolf B, Grier RE, Allen RJ, Goodman SI, Kein CL, Parker WD: Phenotypic variations in biotinidase deficiency. J Pediatr 1983; 103: $233-237$.

2 Wolf B: Worldwide survey of neonatal screening for biotinidase deficiency. J Inher Metab Dis 1991; 14: 923 -927.

3 Cole H, Reynolds TR, Lockyer JM et al: Human Serum Biotinidase: cDNA cloning, sequence, and characterization. J Biol Chem 1994; 269: 6566-6570.

4 Cole-Knight H, Reynolds TR, Meyers GA, Pomponio RJ, Buck GA, Wolf B: Structure of the human biotinidase gene. Mamm Genome 1998; 9: 327 -330.

5 Pomponio RJ, Hymes J, Reynolds TR et al: Mutations in the human biotinidase gene that cause profound biotinidase deficiency in symptomatic children: molecular, biochemical, and clinical analysis. Pediat Res 1997; 42: 840-848.

6 Pomponio RJ, Norrgard KJ, Hymes J et al: Arg538 to cys mutation in a CpG dinucleotide of the human biotinidase gene is the second most common cause of profound biotinidase deficiency in symptomatic children. Hum Genet 1997; 99: 506-512.

7 Pomponio RJ, Yamaguchi A, Arashima S, Hymes J, Wolf B: Mutation in a putative glycosylation site (N489T) of biotinidase in the only known Japanese child with biotinidase deficiency. Mol Genet Metab 1998; 64: 152 - 154.

8 Norrgard KJ, Pomponio RJ, Swango KL et al: Mutation (Q456H) is the most common cause of profound biotinidase deficiency in children ascertained by newborn screening in the United States. Biochem Molecul Med 1997; 61: 22-27.

9 Norrgard KJ, Pomponio RJ, Hymes J, Wolf B: Mutations causing profound biotinidase deficiency in children ascertained by newborn screening in the United States occur at different frequencies than in symptomatic children. Ped Res 1999; 46: $20-27$. 
10 Rychlik W, Rhoads RE: A computer program for choosing optimal oligonucleotide primers for filter hybridization, sequencing and in vitro amplification. Nucleic Acids Res 1989; 17: $8543-8551$

11 Sheffield VC, Cox DR, Lerman LS, Myers RM: Attachment of a 40 base pair $\mathrm{G}+\mathrm{C}$ rich sequence (GC clamp) to genomic DNA fragments by the polymerase chain reaction results in improved detection of single-base changes. Proc Natl Acad Sci USA 1989; 86: $23632-23637$.

12 Lerman LS, Silverstein K: Computational simulation of DNA melting and its application to denaturing gradient gel electrophoresis. Methods Enzymol 1987; 155: $121-130$.

13 Myers RM, Maniatis T, Lerman LS: Detection and localization of single base changes by denaturing gradient-gel electrophoresis. Methods Enzymol 1987; 155: 501-527.
14 Cremonesi L, Carrera P, Fumagalli A et al: Validation of double gradient denaturing gradient gel electrophoresis through multigenic retrospective analysis. Clin Chem 1999; 45: 35 - 40.

15 Sourmala TM, Baumgartner ER, Wick H, Scheibenreiter S: Comparison of patients with complete and partial biotinidase deficiency: biochemical studies. J Inher Metab Dis 1990; 13: 76 92.

16 Norrgard KJ, Pomponio RJ, Swango KL et al: Double mutation $(\mathrm{A} 171 \mathrm{~T}$ and $\mathrm{D} 444 \mathrm{H})$ is a common cause of profound biotinidase deficiency in children ascertained by newborn screening in the United States. Hum Mutation 1998; 11: 410-414.

17 Swango KL, Demirkol M, Hüner G et al: Partial biotinidase deficiency is usually due to the $\mathrm{D} 444 \mathrm{H}$ mutation in the biotinidase gene. Hum Genet 1998; 102: 571-575. 